centrations. Again, the results (Table 1) show a similar pattern for both inhibitors, although on a dry weight basis the amount of inhibition was much less in glucose than in peas.

Varga and Ferenczy ${ }^{8}$ detected 'inhibitor $\beta$ ' in fruits of thirty different species belonging to ten families and the many references listed by Ferenczy ${ }^{9}$ illustrate its widespread occurrence. This report, the fact that glucose is prepared from plant sources, and the identical position on chromatograms prepared with five different solvents suggest a possible similarity between the inhibitor found in peas, and glucose. Apart from this suggestion, this communication is intended as a warning against the use of inadequately purified glucose when partitioning extracts which are to be assayed for growth substances by the coleoptile straight growth test.

R. F. M. VAN Steveninck Crop Research Division,

Department of Scientific and Industrial Research, Christchurch, New Zealand.

'Boysen Jenssen, P., Planta, 31, 653 (1941).

${ }^{2}$ Gordon, S. A., and Sanchez Nieva, F., Arch. Biochem., 20, 356 (1949)

${ }^{3}$ Hemberg, T., Physiol. Plant, 2, 24 and 37 (1949).

+ Luckwill, L. C., and Woodcock, D., Ann. Rep. Long Ashton Res. Sta., $23(1950)$.

- Libbert, E., Planta, 45, 68 and 405 (1955).

'Nitsch, J, P., and Nitsch, C., Beitr. Biol. Pflanz., 31, 387 (1955).

7 Nitsch, J. P., and Nitsch, C., Plant Physiol., 31, 94 (1956).

'Varga, M., and Ferenczy, L., Naturwiss., 44, 398 (1957).

${ }^{9}$ Ferenczy, L., Phyton, 9, 47 (1957).

\section{Use of Lyophilized Formol-treated Red Cells in Blood-Group Serology}

Moskowitz and $\mathrm{Carb}^{1}$ have reported that treatment of human red cells with formalin inhibits their agglutinability without impairing their absorptive power for the corresponding blood-group agglutinin. During the course of a similar investigation, we have confirmed these findings and also the observation of Weinbach ${ }^{2}$ that formol-treated red cells are sufficiently 'toughened' to withstand freeze-drying by lyophilization. We have found that such lyophil ized cells re-suspended in normal saline retain their original absorptive capacity for blood-group agglutinins, and that eluates prepared from these cells by Landsteiner's heat method, following absorption, are as active as those from untreated cells. No hæmolysis has occurred during elution.

So far as we are aware, lyophilized formol-treated red cells have not previously been put to practical use in blood-group serology, and we wish therefore to direct attention to a practical application of this technique. We encountered recently a sample of red cells which reacted similarly to certain rare cells described by Weiner et al. ${ }^{3}$ and given the symbol $A_{m}$, which showed a marked hæmolysis when we attempted to store them at low temperature in glycerol. These red cells were not agglutinated by group $\mathrm{O}$ immune type anti-A sera but readily absorbed anti-A. Exposure to formol-saline and lyophilization enabled these cells to be preserved satisfactorily without impairing their power of absorption and subsequent elution.

The technique we have used in the initial treat. ment with formalin differs in some respects from that of Moskowitz and Carb and is as follows. One volume of formaldehyde solution (analytical reagent, approximately 36 per cent $w / v$ HCHO) diluted 1 in 30 with non-buffered normal saline is incubated at $37^{\circ} \mathrm{C}$. with an equal volume of washed packed red cells. After 12-24 hr. incubation the treated red cells are washed three times in normal saline and then dried from the frozen state. If immediate lyophilization is not convenient, the formol-treated cells may be stored under distilled water at $4-6^{\circ} \mathrm{C}$. Storage under distilled water has proved more satisfactory than under normal saline since, while some degree of hæmolysis tends to occur with the latter, formoltreated red cells stored for up to one week under distilled water have shown no trace of hæmolysis.

\section{E. R. GoLD \\ W. J. LOCKYER \\ GeOfFrey H. TOVeY}

National Blood Transfusion Service,

Southmead, Bristol. July 28.

' Moskowitz, M., and Carb, S., Nature, 180, 1049 (1957).

${ }^{2}$ Weinbach, R., Microbiol. Parazitol. si Epidemiol., 3, 213 (1958).

${ }^{3}$ Weiner, W., Lewis, H. B. M.., Moores, Phyllis, Sanger, Ruth, and Race, R. R., Vox Sanguinis, 2,25 (1957).

\section{Relationship between Certain Biological Constants and Trophic Condition in Mosquito Populations}

MACDONALD ${ }^{1}$ has shown that the composition of mosquito populations, as regards the proportion in the parous state, can be calculated theoretically, yielding an equation which involves the daily sur. vival-rate and a time period based on the gonotrophic cycle. This, and a modified equation given by Davidson ${ }^{2}$, have provided a useful means for calculating daily survival rates in the field. Using similar methods, it is possible to derive a general expression which determines the composition of populations as regards the proportion in the unfed condition.

Assuming a population in a steady equilibrium, with a daily hatch of $M$ mosquitoes, and a daily survival-rate of $p$, then the number aged $x$ days will be $M p x$. Then let : $n=$ days from hatch to first feed; $d=$ days developing eggs, up to the first oviposition ; $f=$ days from oviposition to next feed ; $c=d+f$.

This cycle will be repeated every $c$ days. Then, numbering the days after emergence $0,1,2, \ldots$ etc., the days on which mosquitoes are in a given state are as shown below :

$$
\begin{array}{lr}
\quad \text { Unfed } & n-1 \\
n+d, n+d+1, n+d+2 & n-2+1 \\
n+c+d, n+c+d+1, n+c+d+2 & n+2 c-1 \\
\quad \text { Fed and/or developing eggs } & \\
& \\
n, n+1, n+2 & n+d-1 \\
n+c, n+c+1, n+c+2 & n+c+d=1 \\
n+2 c, n+2 c+1, n+2 c+2 & n+2 c+d-1
\end{array}
$$

Let $G=$ number which are fed and/or developing eggs ;

$$
\begin{aligned}
& \text { then } G=M\left(p^{n}+p^{n+c}+p^{n+2 c} \ldots\right. \\
& +p^{n+1}+p^{n+c+1}+p^{n+2 c+1} \ldots \\
& \left.+p^{n+l-1}+p^{n+c+d-1}+p^{n+2 c+d-1} \ldots\right) \\
& =M\left(\frac{p^{n}}{1-p^{c}}+\frac{p^{n-1}}{1-p^{c}}+\frac{p^{n+2}}{1-p^{c}} \cdots+\frac{p^{n+d-1}}{1-p^{c}}\right) \\
& =\frac{M}{1-p^{c}}\left[\left(p^{n}+p^{n+1}+p^{n+2} \ldots+p^{\infty}\right)-\right. \\
& \left.\left(p^{n+d}+p^{n+d+1}+p^{n+d+2} \ldots+p^{\infty}\right)\right] \\
& =\frac{M}{1-p^{c}}\left(\frac{p^{n}}{1-p}-\frac{p^{n+d}}{\mathrm{l}-p}\right) \\
& =\frac{M\left(p^{n}-p^{n+d}\right)}{(1-p)\left(1-p^{c}\right)}
\end{aligned}
$$

